\title{
Solid-State Fermentation in Brewer's Spent Grains by Fusarium fujikuroi for Gibberellic Acid Production
}

\author{
Lucas Rodolfo Inácio da Silva ${ }^{1}$ (D), Cristiano José de Andrade ${ }^{1}$ (D), Débora de Oliveira ${ }^{1 D}$, Lindomar \\ Alberto Lerin 2 (iD) \\ 1 Department of Chemical Engineering and Food Engineering, Federal University of Santa Catarina - UFSC, CEP: 88010- \\ 970, Florianópolis, Brazil \\ 2 Laboratory of Agroecology, Federal University of Fronteira Sul - UFFS, Erechim campus, RS-135, Rural Area, CEP: \\ 99700-970, Erechim, Brazil \\ * Correspondence: lindolerin@gmail.com;
}

Scopus Author ID 35327547000

Received: 3.01.2021; Revised: 26.01.2021; Accepted: 1.02.2021; Published: 7.02.2021

\begin{abstract}
The search for new production methodologies of gibberellic acid $\left(\mathrm{GA}_{3}\right)$, such as solid-state fermentation (SSF), and the use of agro-industrial waste are important to lower production costs. Therefore, the aim of this study was $\mathrm{GA}_{3}$ production by Fusarium fujikuroi on SSF mode using brewer's spent grains (BSG). BSG presents in its composition components that are known to be excellent inducers of metabolite production, showing, this way, its potential to be used as the substrate in biotechnological processes. Optimization of $\mathrm{GA}_{3}$ production was carried out using a $2^{2}$ central composite design, considering the effects of moisture content, temperature, and fermentation time. The highest mycelial growth and $\mathrm{GA}_{3}$ production $\left(0.82 \mathrm{~g} . \mathrm{Kg}^{-1}\right)$ was obtained in the condition of $80 \%$ moisture content, $28{ }^{\circ} \mathrm{C}$ in 96 hours of fermentation. These results suggest that the SSF using BSG as the medium for the growth of $F$. fujikuroi is a viable way to $\mathrm{GA}_{3}$ produce.
\end{abstract}

Keywords: gibberellic acid; brewer's spent grains; solid-state fermentation; Fusarium fujikuroi.

(C) 2021 by the authors. This article is an open-access article distributed under the terms and conditions of the Creative Commons Attribution (CC BY) license (https://creativecommons.org/licenses/by/4.0/).

\section{Introduction}

Gibberellins are phytohormones resulting from secondary metabolites. They are also important biotechnological products, with great economic value, used in agriculture as natural plant growth hormones [1]. They play a role in breaking flowering dormancy, increasing flowering initiation, increasing stunted plants, spurring germination processes [2-5]. Gibberellins are chemically composed of diterpenoids consisting of tetracyclic entgibberellane carbon skeletal structure arranged in four or five rings [6,7].

Gibberellic acid $\left(\mathrm{GA}_{3} ; \mathrm{C}_{19} \mathrm{H}_{22} \mathrm{O}_{6} ; \mathrm{MM}=346.37\right)$ is chemically characterized as a tetracyclic dihydroxy- $\gamma$-lactone acid-containing $\mathrm{C} 1-\mathrm{C} 2$ double bond, $\mathrm{C} 10 \gamma$-lactone ring and an $\mathrm{OH}$ group in $\mathrm{C} 13$; it is one of the most important compounds of gibberellins and plays an important role in plant growth as a natural hormone. Plants and some microorganisms, such as fungi and bacteria, can produce this molecule. For the agro-industrial sector, it has promising applications because it is related to plant growth. Since its discovery, studies have focused on increasing yield, productivity, and, mainly, reducing production costs so that its use is not restricted. It is applied in crops, orchards, and ornamental plants, playing a role in seed germination, response to abiotic stress, fruit growth enhancement, stem elongation, flowering, 
barley malting, and interactions with other phytohormones that lead to other physiological effects $[8,9]$.

$\mathrm{GA}_{3}$ is presently produced on a commercial scale through submerged fermentation by Fusarium fujikuroi. However, low yields and costly downstream processes greatly increase the expenses of $\mathrm{GA}_{3}$ production by submerged fermentation [10,11]. This technological route's disadvantages lead to the prospecting of new processes aimed mainly at increasing the amount of product obtained per reactor volume, with solid-state fermentation (SSF) for the $\mathrm{GA}_{3}$ production being an interesting alternative. With the SSF, it is usually possible to obtain greater amounts of the desired metabolite $\left(\mathrm{GA}_{3}\right)$, as it represents the conditions closest to these microorganisms' natural habitat. These conditions hinder unwanted contamination by bacteria. The literature shows that SSF has economic advantages in the face of submerged fermentation. As examples, the authors cite a wide range of agro-industrial wastes used in the process and that greater production of biomass and metabolites is achieved [12-15].

An agro-industrial country, such as Brazil, generates large amounts of wastes. These come from the industrial processing of sugarcane, citrus, corn, rice, soy, coffee, castor, sunflower, barley, malt, cassava, among others, and they have great potential for use in bioprocesses to produce high value-added bioproducts.

Several authors have been conducting studies to produce $\mathrm{GA}_{3}$ by SSF using agroindustrial waste as substrates. Among the agro-industrial waste used, we can cite wheat bran [16-18], cassava [19], coffee husk [20], soybean hulls [21], citric pulp [10,21,22], pigeon pea pods, sorghum straw, corncobs [23], corn stalks [24], jatropha seed cake [25], and rice bran and malt [26].

Worldwide the quantity of craft beer industries is increasing. Brazil in 2019 reached the mark of 1,2091 registered breweries. The growth in the number of establishments has been constant over the past 20 years, with an average growth rate of $19.6 \%$ per year. This growth rate has recently grown, being $36.4 \%$ if the last 5 years' period is analyzed [27-31]. Malt bagasse comes from the process of obtaining the must by boiling ground malt and adjuncts. Research shows quantities of 14-20 Kg of residue per 100 liters of beer produced [32,33], and the chemical composition of this residue varies as per the variety and harvesting time of the barley, malt grinding conditions, and type of adjuncts (corn, rice, wheat, and sorghum) incorporated in the brewing process [34]. Thus, the brewery wastes from the craft beer industry represent a serious environmental hazard. The brewing process generates a wide variety of wastes such as brewer's spent grain, hot trub, and residual yeast, whose amount generated cannot be reduced due to their generation stages, which are indispensable to the production process [35]. These residues have several components with significant nutritional value, such as carbohydrates, proteins, amino acids, phenolic compounds, vitamins, fibers, and minerals, as they have a high organic matter content [36-39]. Since they are abundant in nutrients such as carbon, nitrogen, and mineral salts, they are an excellent medium for the growth of fungi used in SSF processes. Otherwise, if disposed of improperly, it can cause significant environmental damage. Therefore, an interesting alternative is to use the brewery wastes as culture media in biotechnological processes, thus being within the green chemistry concept. Given the foregoing, this work aimed to optimize the phytohormone GA3 production by solidstate fermentation of brewer's spent grain by Fusarium fujikuroi. 


\section{Materials and Methods}

\subsection{Substrates.}

The brewer's spent grain (BSG) was kindly provided by On Tap brewery (São José $\mathrm{SC} / \mathrm{Brazil})$. The BSG was transported to the laboratory at room temperature. It was dried at 50 ${ }^{\circ} \mathrm{C}$ until constant mass. Then, BSG was stored in hermetically sealed bags at room temperature. The dry BSG was characterized: moisture $\left(135^{\circ} \mathrm{C}\right.$ for $2 \mathrm{~h}$ ), protein (Kjeldahl method), fat (Soxhlet extraction with ethyl ether), starch (absorbance at $510 \mathrm{~nm}$ ), and total sugars (Lane Enyon) [40].

\subsection{Inoculum preparation.}

Fusarium fujikuroi IOC 4380 was kindly donated by Coleção de Culturas de Fungos Filamentosos - CCFF (Filamentous Fungus Culture Collection), FIOCRUZ - IOC (Rio de Janeiro, Brazil) and maintained in commercial culture medium potato dextrose agar - PDA (Kasvi, Bazil).

F. fujikuroi was activated on PDA Petri dish at $28^{\circ} \mathrm{C}$ for 10 days. Then to define the time and quantity of discs to be used for the inoculum preparation, tests were performed on $100 \mathrm{~mL}$ Erlenmeyer with $30 \mathrm{~mL}$ of potato dextrose broth (Himedia, Brazil) enriched with 2 g.L $\mathrm{L}^{-1}\left(\mathrm{NH}_{4}\right)_{2} \mathrm{SO}_{4}, 1$ g.L ${ }^{-1} \mathrm{FeSO}_{4} .7 \mathrm{H}_{2} \mathrm{O}, 1$ g.L $\mathrm{L}^{-1} \mathrm{MnSO}_{4} . \mathrm{H}_{2} \mathrm{O}, 0.5$ g.L $\mathrm{L}^{-1} \mathrm{MgSO}_{4}$ and pH 5-5.5 [1]. Erlenmeyer flasks were sterilized in an autoclave at $121{ }^{\circ} \mathrm{C}$ for $15 \mathrm{~min}$. After, 2 or 3 discs $(\varnothing$ $12 \mathrm{~mm}$ each) taken from $F$. fujikuroi culture in PDA were added. The tests were conducted in an orbital shaker (TECNAL, TE-240, Brazil) at $120 \mathrm{rpm}$ and a temperature of $28{ }^{\circ} \mathrm{C}$ for up to 96 hours [41]. The biomass was determined by the dry matter methodology, in which the culture medium was filtered on quantitative filter paper, and the oven (Solab, Brazil) dried at $80{ }^{\circ} \mathrm{C}$ until constant weight. All tests were performed in triplicate.

For the GA3 production assays, the inoculum was prepared in $250 \mathrm{~mL}$ Erlenmeyer, where each one contained $100 \mathrm{~mL}$ of culture medium and 3 discs under the same conditions described above. The biomass was separated from the culture medium by filtration using a quantitative filter paper, and then the biomass was added to the BSG to start fermentation.

\subsection{Solid state fermentation (SSF) of brewer's spent grain (BSG).}

SSFs in $500 \mathrm{~mL}$ flasks were carried out, which $50 \mathrm{~g}$ of BSG were supplemented with 40 g. $\mathrm{Kg}^{-1}$ glucose, 1 g. $\mathrm{Kg}^{-1} \mathrm{FeSO}_{4} .7 \mathrm{H}_{2} \mathrm{O}, 0.5$ g. $\mathrm{Kg}^{-1} \mathrm{MgSO}_{4}, 1$ g. $\mathrm{Kg}^{-1} \mathrm{MnSO}^{4} . \mathrm{H}_{2} \mathrm{O}$, and 0.2 g. $\mathrm{Kg}^{-1} \mathrm{ZnSO}_{4} .7 \mathrm{H}_{2} \mathrm{O}$ and $\mathrm{pH}$ 5-5.5, all supplementation components were added relative to BSG mass [1]. Flasks were sterilized in an autoclave at $121^{\circ} \mathrm{C}$ for $15 \mathrm{~min}$. Then, in each flask was added the inoculum, prepared as described in item inoculum preparation (item 2.2), at a ratio of $15 \%$ to the mass of BSG and homogenized [10,20].

For the optimization step, a $2^{2}$ central composite design (CCD) was adopted [42], with a duplicate of the factorial assays and triplicate experiments at a central point, totalizing 11 experiments, in which the independent variables studied were: moisture content (60 to 80\%) and temperature $\left(28\right.$ to $35^{\circ} \mathrm{C}$ ), keeping constant the inoculum ratio of $15 \%$ to the mass of $\mathrm{BSG}$, fermentation time of 96 hours, and aeration by diffusion. Statistical analyses were performed using online software Protimiza Experimental Design (http://experimentaldesign.protimiza.com.br/) and a level of significance of $95 \%(\mathrm{p}<0.05)$. 
After fermentation conditions optimization for the $\mathrm{GA}_{3}$ production, a kinetic experiment was carried out under the following conditions: moisture content of $80 \%$ and temperature of $28^{\circ} \mathrm{C}$. At the end of each determined time ( 24 to 120 hours), the GA3 production was evaluated.

\subsection{Analytical procedure.}

\subsubsection{Fungal growth.}

Microbial growth in the BSG was determined according to the adapted Standard Methods G21-15 [43]: 0 - absence of growth; 1 - little growth, small fragments of mycelium thrown into the culture medium; 2 - moderate growth, the appearance of fine pellet on the surface of the culture medium; 3 - great growth, the appearance of mycelium in more than half of the medium.

\subsubsection{Extraction of $\mathrm{GA}_{3}$.}

For the extraction of $\mathrm{GA}_{3}, 15 \mathrm{~g}$ of the fermented were used, with phosphate buffer ( $\mathrm{pH}$ $=8.0)$ ratio $1: 3(\mathrm{w}: \mathrm{v})$ and then placed under orbital shaking at $120 \mathrm{rpm}$ and $25^{\circ} \mathrm{C}$ for $20 \mathrm{~min}$. Afterward, liquid-liquid extraction was performed using 1:1 (v:v) ethyl acetate. The organic phase was recovered by using separating funnels and then route-evaporated at $50{ }^{\circ} \mathrm{C}$ and 10 rpm for reducing the volume of solvent (5\% - initial volume) $[10,44]$. Then, the crystals of $\mathrm{GA}_{3}$ were dissolved in $10 \mathrm{~mL}$ of ethanol (Merck, 99\% purity) [45].

\subsection{3. $\mathrm{GA}_{3}$ content.}

The $\mathrm{GA}_{3}$ content was measured by the spectrophotometric method described by Holbrook et al. [46] and Berríos et al. [44]. After extraction, $1 \mathrm{~mL}$ of the sample was transferred to a volumetric flask $(10 \mathrm{~mL})$, and the volume was adjusted with $\mathrm{HCl}$ at $3.75 \mathrm{M}$. Then, the absorbance at $254 \mathrm{~nm}$ was measured and analyzed by a $\mathrm{GA}_{3}$ (Sigma-Aldrich, 90\% purity) calibration curve for determining the $\mathrm{GA}_{3}$ production (g. $\mathrm{Kg}^{-1}$ of $\mathrm{BSG}$ ).

\subsubsection{Water activity $\left(\mathrm{a}_{\mathrm{w}}\right)$.}

The $\mathrm{a}_{\mathrm{w}}$ of the BSG was determined on the Aqualab equipment (Decagon Devices). After calibrating the equipment, $3 \pm 0.2 \mathrm{~g}$ of the sample were placed in the instrument, and the reading was performed automatically.

\section{Results and Discussion}

\subsection{Brewer's spent grain (BSG) characterization.}

The dry BSG (dry basis) is composed of $8 \%$ moisture and $19.4 \%$ protein, $14.3 \%$ fat, $15.9 \%$ starch, and $12.8 \%$ total sugars. The results agree with the literature where, for Santos et al. [22], the moisture was between 8.7 and $10.8 \%$, protein content $24.2 \%$, fat content $3.9 \%$, and ash content $3.4 \%$. For Cordeiro et al. [32], the humidity was $75.4 \%$, ashes $1.2 \%$, carbohydrates $15.4 \%$, total proteins $5.37 \%$, total fats $2.43 \%$, and crude fiber $3.98 \%$. Mathias et al. [37] reported the brewer's spent grain composition showed high moisture (86\%), ash of $3.8 \%$, total organic carbon of $52 \%$, total nitrogen of $4.3 \%$, total protein of 26.9 and, carbon to nitrogen ratio of 12.1. For Mussatto et al. [47], the protein and extractive components were 
$22.4 \%$ and $4.6 \%$ ash in brewer's spent grain. Thus, BSG is well-balanced in terms of amino acids, fatty acids, and carbon sources [36,37]; that is, BSG can be used as the alternative substrate in the biotechnological process, as in the fungal GA3 production.

\subsection{Inoculum growth.}

The amount of mycelial mass present in the inoculum is one of the main factors observed in fermentation processes. Therefore, F. fujikuroi growth kinetics was evaluated to determine the maximum mycelial mass in the shortest time. For this, the microorganism grown in commercial PDA, 2 or 3 discs, was transferred to potato dextrose broth with mineral supplementation at $28^{\circ} \mathrm{C}$ and $120 \mathrm{rpm}$ for up to 96 hours for growth estimation. Figure 1 shows that the largest amount of dry mass was found in 48 hours using 3 discs $\left(6.3\right.$ g.L $\left.\mathrm{L}^{-1}\right)$. For both assays, it was noted that in 48 hours, the microorganism reaches the maximum growth in mycelial mass, and, after this time, a small increase in mycelial mass was observed (Figure 1). Thus, 3 discs containing $F$. fujikuroi and inoculum grew for 48 hours were adopted in the work sequence (mycelial mass $<6$ g.L $\mathrm{L}^{-1}$ ).

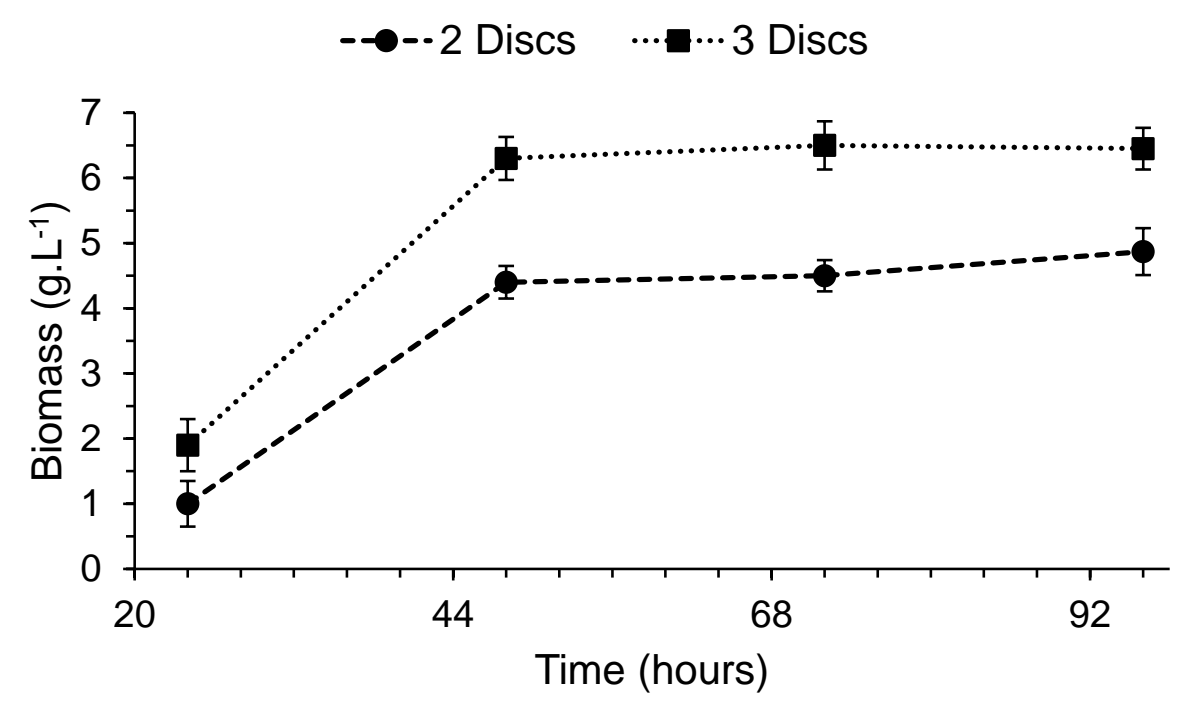

Figure 1. Kinetic evaluation of Fusarium fujikuroi mycelial growth for inoculum preparation. Experimental condition: potato dextrose broth with mineral supplementation at $28{ }^{\circ} \mathrm{C}$ and $120 \mathrm{rpm}$.

\subsection{Optimization of $G A_{3}$ production by SSF.}

For Singhania et al. [48] and Rios-Iribe et al. [49], the physical factors that affect the growth of microorganisms and $\mathrm{GA}_{3}$ production are temperature, moisture, $\mathrm{pH}$, agitation, aeration, and/or water activity. Thus, it is essential for the biotechnological processes to search for the best process conditions. For this, the experimental design methodology was used for the $\mathrm{GA}_{3}$ production optimization by SSF. The matrix of the $2^{2} \mathrm{CCD}$ with coded and real values of the independent variables and the responses in GA3 production and mycelial growth are shown in Table 1.

Table 1. The matrix of the $2^{2} \mathrm{CCD}$ experimental design (coded and real values) for optimization of $\mathrm{GA}_{3}$ production and mycelial growth by SSF of BSG in 96 hours.

\begin{tabular}{|c|c|c|c|c|c|c|}
\hline \multirow[b]{2}{*}{ Run } & \\
\hline & $\begin{array}{c}\text { Moisture content } \\
-\mathbf{X}_{1}(\%) \\
\end{array}$ & $\begin{array}{c}\text { Temperature } \\
-\mathrm{X}_{2}\left({ }^{\circ} \mathrm{C}\right) \\
\end{array}$ & $\begin{array}{c}\mathrm{GA}_{3} \text { production } \\
\left(\mathrm{g} . \mathrm{Kg}^{-1}\right)\end{array}$ & $\begin{array}{c}\text { Predicted } \mathrm{GA}_{3} \\
\text { production }\left(\mathrm{g.Kg} \mathrm{Kg}^{-1}\right)^{1}\end{array}$ & $\begin{array}{c}\text { Relative } \\
\text { error }(\%)^{2}\end{array}$ & $\begin{array}{l}\text { Mycelial } \\
\text { growth }^{3} \\
\end{array}$ \\
\hline 1 & $-1(60)$ & $-1(28.0)$ & 0.54 & 0.51 & 5.56 & 2 \\
\hline $1^{\dagger}$ & $-1(60)$ & $-1(28.0)$ & 0.53 & 0.51 & 3.77 & 2 \\
\hline 2 & $1(80)$ & $-1(28.0)$ & 0.80 & 0.79 & 1.25 & 3 \\
\hline \multicolumn{6}{|c|}{ https://biointerfaceresearch.com/ } & 13046 \\
\hline
\end{tabular}




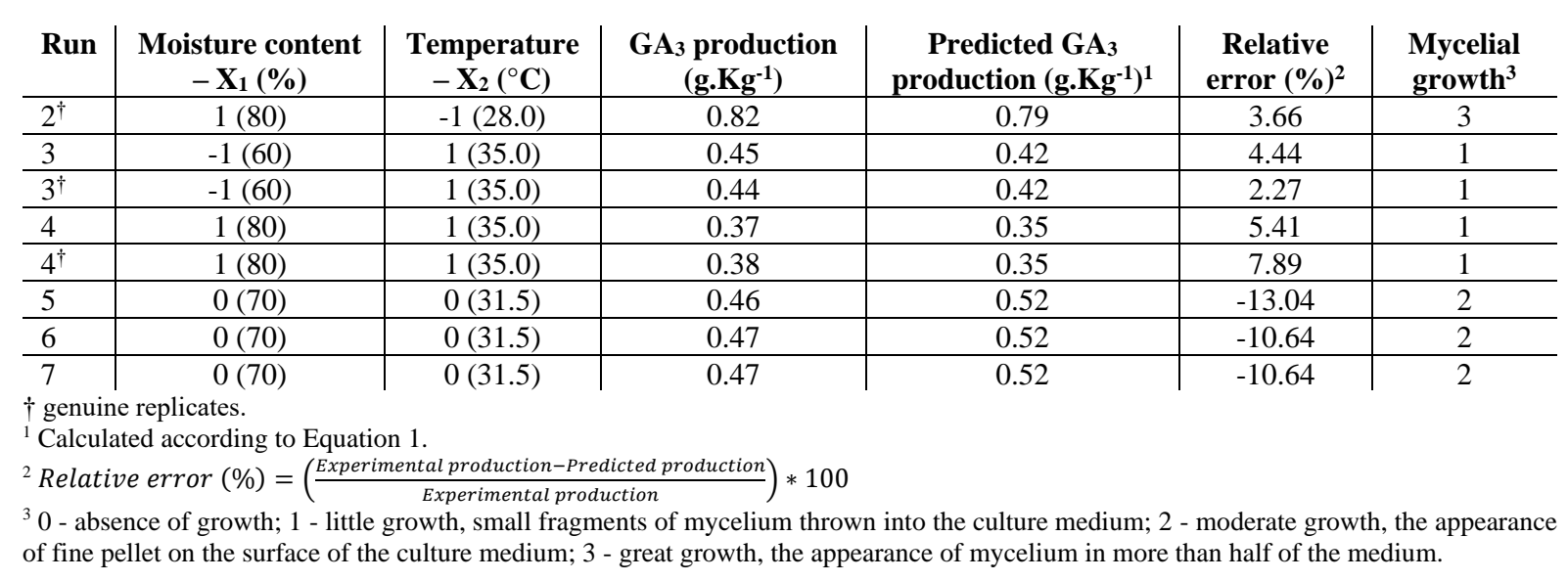

The main variables for fermentation, for both SSF and submerged, are the moisture content and aw, limiting microbial growth and, consequently, metabolite production and the product's efficiency. Also, the effect of aw may be different on the growth and metabolite production [50]. With this, the $\mathrm{a}_{\mathrm{w}}$ of BSG in different moisture contents was evaluated. BSG aw with the moisture content of 60,70 , and $80 \%$ was greater than 0.98 . These $a_{w}$ levels make feasible the growth of bacteria, yeasts, and mold, including $F$. fujikuroi. Corona et al. [50] confirmed this fact when carrying out studies on the influence of $a_{w}$ to produce $\mathrm{GA}_{3}$ by $F$. fujikuroi, showing that the optimal range of $\mathrm{a}_{\mathrm{w}}$ is between 0.98 and 0.99 . With these results, the $a_{w}$ of this work provides conditions for good mycelial growth.

The visual characteristic of microbial growth under the experimental conditions of Table 1 can be visualized in Figure 2. Growth was classified as moderate (2) in runs 1, 5, 6, and 7 (Figure 2a,e), as a result of the appearance of a fine pellet on the surface of the BSG and the mycelial mass was present in less than half of the biomass used. For run 2, it was noted an excellent (3) mycelial growth throughout the BSG (Figure 2b), where it was also observed the greater $\mathrm{GA}_{3}$ production. In runs 3 and 4 (Figure $2 \mathrm{c}, \mathrm{d}$ ), little (1) colonization of the substrate of fermentation was observed due the low mycelial growth, indicating that the conditions that used higher temperature were not propitious for the growth of $F$. fujikuroi. These results are following the study of Machado et al. [51], who evaluated the growth kinetics of $F$. fujikuroi and $\mathrm{GA}_{3}$ production using solid substrates and observed that a great mycelial growth occurred at $28{ }^{\circ} \mathrm{C}$ and high moisture content.

Independent of the moisture content and temperatures employed, by visual analysis, it is possible to state that the $F$. fujikuroi could grow in the BSG. However, higher $\mathrm{GA}_{3}$ production was achieved using high humidity (80\%) and lower temperatures $\left(28{ }^{\circ} \mathrm{C}\right)$. According to Machado et al. [20], GA 3 is a secondary metabolite. Thus, there is no direct relation between fungal biomass and $\mathrm{GA}_{3}$ production, which is aligned with experimental design data, where production occurred in all conditions evaluated. Nevertheless, analysis of CCD data indicates that fungal growth is a relevant factor to be analyzed to achieve high production of $\mathrm{GA}_{3}$ (Table 1). According to Cuali-Álvarez et al. [52] and Díaz et al. [53], when producing $\mathrm{GA}_{3}$ by $F$. fujikuroi, it could be inferred that fungal growth was an important factor to obtain higher concentrations of the metabolite when using sewage sludge and welsh onion waste.

Among the conditions studied, the variation in $\mathrm{GA}_{3}$ production ranged from 0.37 to 0.82 g. $\mathrm{Kg}^{-1}$ (Table 1). This Table shows the good experimental reproducibility, which showed similar values in the central points (runs 5,6 , and 7), with a $\mathrm{GA}_{3}$ production of $0.46,0.47$, and $0.47 \mathrm{~g} . \mathrm{Kg}^{-1}$, respectively. 

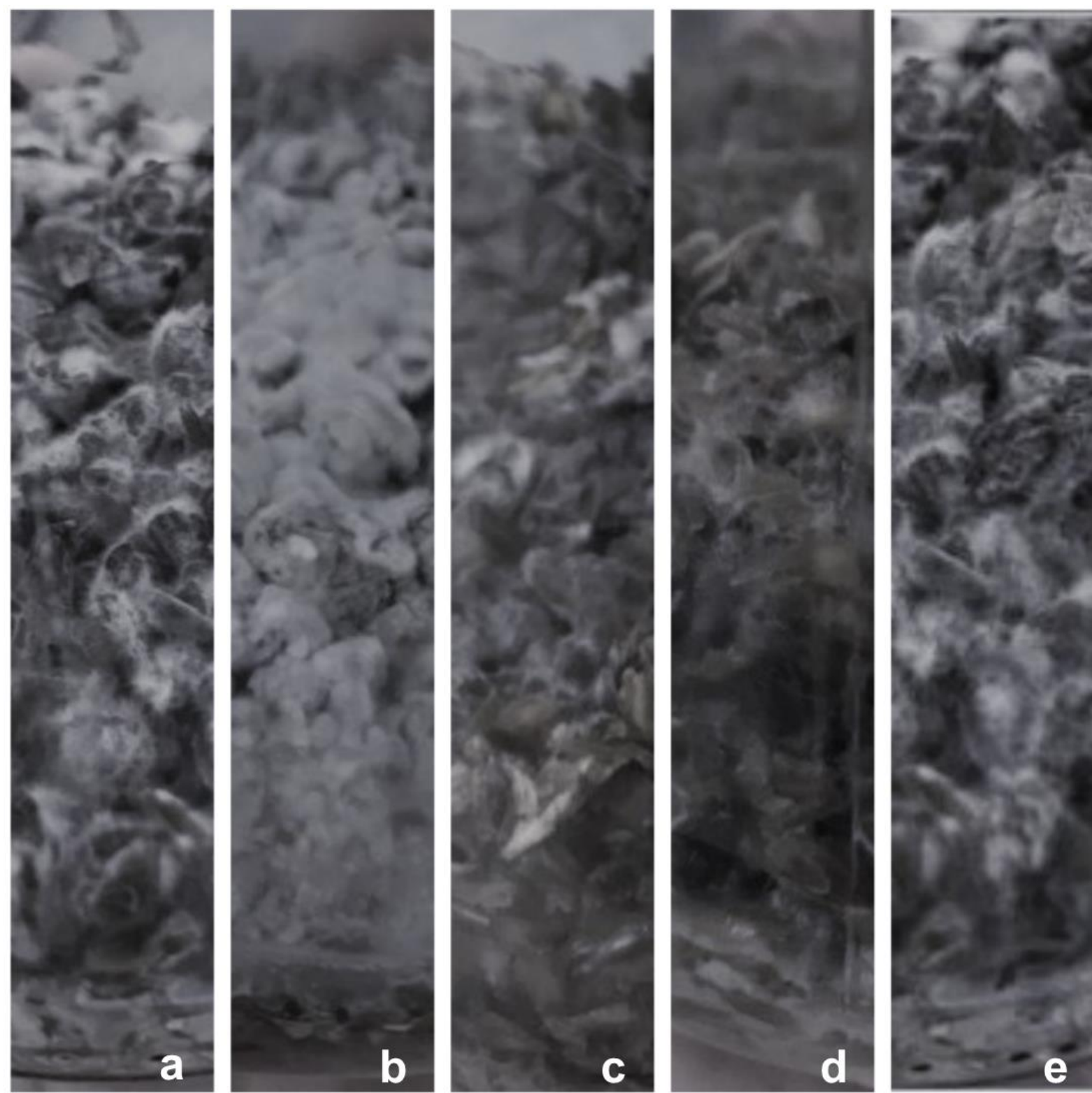

Figure 2. Fusarium fujikuroi mycelial growth by SSF of BSG under the experimental conditions of Table 1.

It can be observed the temperature showed a significant negative effect, where with the decrease of the temperature, the GA3 production was increased. On the other hand, a positive effect on $\mathrm{GA}_{3}$ production was observed for the studied range's moisture content (see runs 1 and 2). Werle et al. [26] and Machado et al. [20] also observed a significant positive effect for moisture on the $\mathrm{GA}_{3}$ production by SSF. With the decrease in temperature and increase in moisture content, the production of $\mathrm{GA}_{3}$ also increases.

These results (Table 1) were similar to those found by Werle et al. [26] using a mixture of crude rice bran and malt waste $\left(0.93 \mathrm{~g} \mathrm{GA}_{3} . \mathrm{Kg}\right.$ of the substrate), and better than those obtained by Machado et al. [20], using cassava bagasse and coffee husk $\left(0.49 \mathrm{~g} \mathrm{GA}_{3} \cdot \mathrm{Kg}^{-1}\right.$ of the substrate), and inferior to those found by Corona et al. [50] with wheat bran and starch (4.5 - $5.0 \mathrm{~g} \mathrm{GA}_{3} . \mathrm{Kg}^{-1}$ of the substrate), Rodrigues et al. [10] from sugarcane bagasse, soy bran, soy and coffee husk, citric pulp and cassava bagasse ( 0.1 - $5.8 \mathrm{~g} \mathrm{GA}_{3} \cdot \mathrm{Kg}^{-1}$ of the substrate), and De Oliveira et al. [22] using citric pulp (7.60 $\mathrm{g} \mathrm{GA}_{3} . \mathrm{Kg}^{-1}$ of the substrate).

With the CCD results, analysis of variance (ANOVA) was performed to evaluate the effect of variables on $\mathrm{GA}_{3}$ production. This analysis carried out an F-test, indicating whether there are significant differences between the averages. The values found in this test were tabled 
$F_{0.95 ; 3 ; 7}=4.34$ and calculated $F=40.58$ and, as the calculated $F$ is 9.35 times higher than tabled $F$, it means that there are statistically significant differences between the averages $(p \leq 0.05)$. The probability of significance ( $p$-value) was 0.00008 . It was also possible to verify the percentage of total variance model, evaluated through the $\mathrm{R}^{2}$, which showed a value of $94.5 \%$, resulting in an empirical mathematical model (Equation 1) expressing the $\mathrm{GA}_{3}$ production $\left(\mathrm{g} . \mathrm{Kg}^{-1}\right)$ as a function of moisture content $(\%)$ and temperature $\left({ }^{\circ} \mathrm{C}\right)$.

$$
\text { GA } A_{3} \text { Production }\left(g * \mathrm{Kg}^{-1}\right)=0.52+0.05 * X_{1}-0.13 * X_{2}-0.09 * X_{1} * X_{2}
$$

Where $\mathrm{X}_{1}$ denotes moisture content and $\mathrm{X}_{2}$ temperature.

Figure 3 shows the response surfaces generated from the statistical analysis. It can be observed that the results were consistent, as previously discussed. Thus, the optimized conditions to produce $\mathrm{GA}_{3}\left(0.82 \mathrm{~g} \cdot \mathrm{Kg}^{-1}\right)$ indicated by this study are those of the run 2 of Table 1 , namely moisture content of $80 \%$, the temperature of $28^{\circ} \mathrm{C}$, and fermentation time of $96 \mathrm{~h}$.

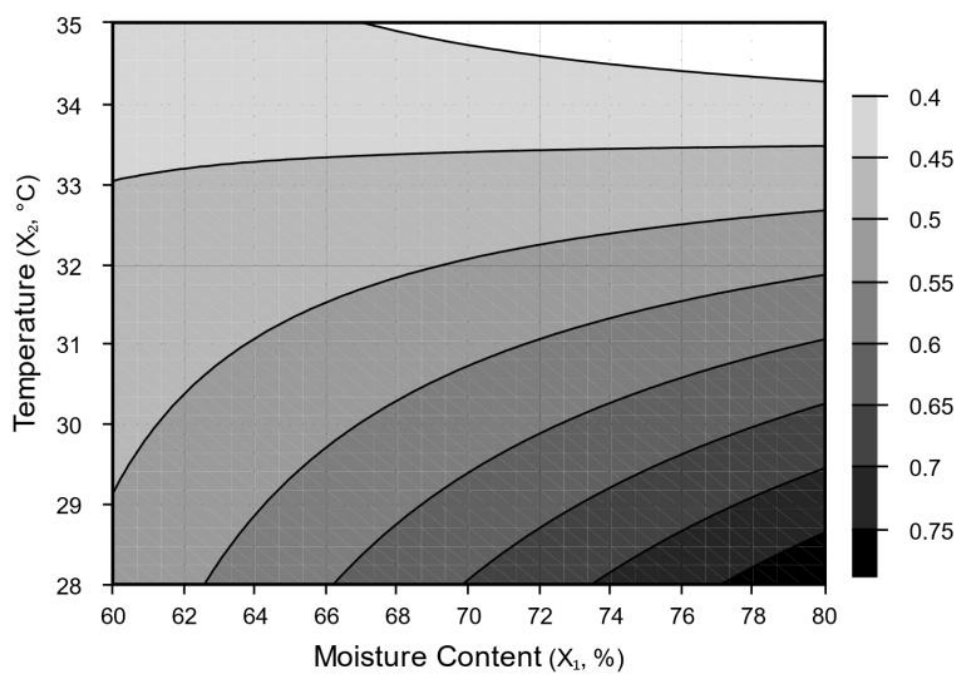

Figure 3. Contour plot of $\mathrm{GA}_{3}$ production by SSF of BSG as a function of moisture content and temperature. Experimental data and conditions are shown in Table 1.

A single solid substrate was used, and a higher GA3 production was achieved in this work. However, Camara et al. [8], addressing the current advances in the GA3 production, reported that higher metabolite production values are achieved when more than one solid substrate is used. Thus, showing that the BSG has great potential to produce $\mathrm{GA}_{3}$ by SSF.

\section{4. $G A_{3}$ production kinetics.}

A kinetic experiment was carried out at the optimized experimental conditions (moisture content of $80 \%$ and temperature of $28^{\circ} \mathrm{C}$ ) for BSG bioconversion in $\mathrm{GA}_{3}$ by SSF, since it provided satisfactory production results and great mycelial growth. The kinetics showed that for the first days of fermentation of BSG for GA3 production was slow, reaching approximately $0.43 \mathrm{~g} . \mathrm{Kg}^{-1}$ in 72 hours. After these 72 hours there was a considerable increase ( 2-fold) in the production of $\mathrm{GA}_{3}$, reaching a maximum production of $0.82 \mathrm{~g} \cdot \mathrm{Kg}^{-1}$ in the total 96 hours of fermentation. After 96 hours, there was a decrease in GA3 production $\left(0.45 \mathrm{~g} . \mathrm{Kg}^{-}\right.$ ${ }^{1}$ ) of approximately 55\%, due to its decomposition into other compounds, according to Machado et al. [20], is a characteristic behavior of kinetics of secondary metabolites such as $\mathrm{GA}_{3}$. It can be inferred that this decomposition of the product in other components is also due to its instability to certain environmental conditions encountered [54]. 
GA3 production kinetics of this study is like those reported by Gelmi et al. [54], Hollmann et al. [55], and the patent deposited by Vidhya and Balu [56].

\section{Conclusions}

The brewer's spent grain showed great potential for use as a substrate in biotechnological processes, mostly due to excellent inducers of metabolites production (protein content and carbon sources). F. fujikuroi was able to grow in the BSG spontaneously and had maximum production of $\mathrm{GA}_{3}\left(0.82 \mathrm{~g} \cdot \mathrm{Kg}^{-1}\right)$. These results demonstrate that the SSF using BSG as the medium for the growth of $F$. fujikuroi is a viable way for the GA3 production. It is necessary to carry out investigations of increase of scale-up, given the use of SSF for industrial $\mathrm{GA}_{3}$ production.

\section{Funding}

This research received no external funding.

\section{Acknowledgments}

This study was financed in part by the Coordenação de Aperfeiçoamento de Pessoal de Nível Superior - Brazil (CAPES) - Finance Code 001. The authors also acknowledge the support received by On Tap brewery (São José - Brazil).

\section{Conflicts of Interest}

The authors declare no conflict of interest.

\section{References}

1. Shukla, R.; Chand, S.; Srivastava, A.K. Batch kinetics and modeling of gibberellic acid production by Gibberella fujikuroi. Enzyme Microb Technol 2005, 36, 492-497, https://doi.org/10.1016/j.enzmictec.2004.11.005.

2. Komatsu, S.; Yang, G.; Unno, K.; Park, P. Characterization of a membrane-associated phosphoprotein (pp47) in rice (Oryza sativa L.) seedlings treated by gibberellin. J Plant Physiol 2002, 159, 121-128, https://doi.org/10.1078/0176-1617-00521.

3. Goldberg-Moeller, R.; Shalom, L.; Shlizerman, L.; Samuels, S.; Zur, N.; Ophir, R.; Blumwald, E.; Sadka, A. Effects of gibberellin treatment during flowering induction period on global gene expression and the transcription of flowering-control genes in Citrus buds. Plant Sci 2013, 198, 46-57, https://doi.org/10.1016/j.plantsci.2012.09.012

4. Kang, S.M.; Radhakrishnan, R.; Khan, A.L.; Kim, M.J.; Park, J.M.; Kim, B.R.; Shin, D.H.; Lee, I.J. Gibberellin secreting rhizobacterium, Pseudomonas putida H-2-3 modulates the hormonal and stress physiology of soybean to improve the plant growth under saline and drought conditions. Plant Physiol Biochem 2014, 84, 115-124, https://doi.org/10.1016/j.plaphy.2014.09.001.

5. El-Sheikh, M.A.; Rajaselvam, J.; Abdel-Salam, E.M.; Vijayaraghavan, P.; Alatar, A.A.; Biji, G.D. Paecilomyces sp. ZB is a cell factory for the production of gibberellic acid using a cheap substrate in solid state fermentation. Saudi J Biol Sci 2020, 27, 2431-2438, https://doi.org/10.1016/j.sjbs.2020.06.040.

6. Kumar, P.K.R.; Lonsane, B.K. Microbial production of gibberellins: State of the art. Adv Appl Microbiol 1990, 34, 29-139, https://doi.org/10.1016/S0065-2164(08)70317-4.

7. Salazar-Cerezo, S.; Martínez-Montiela, N.; García-Sáncheza, J.; Pérez-y-Terrón, R.; Martínez-Contrerasa, R.D. Gibberellin biosynthesis and metabolism: A convergent route for plants, fungi and bacteria. Microbiol Res 2018, 208, 85-98, https://doi.org/10.1016/j.micres.2018.01.010.

8. Camara, M.C.; Vandenbergue, L.P.S.; Rodrigues, C.; Oliveira, J.; Faulds, C.; Bertrand, E.; Soccol, C.R. Current advances in gibberellic acid $\left(\mathrm{GA}_{3}\right)$ production, patented, technologies and potential applications. Planta 2018, 248, 1049-1062, https://doi.org/10.1007/s00425-018-2959-x.

9. Shi, T.-Q.; Gao, J.; Wang, Wei.-J.; Wang, K.-F.; Xu, G.-Q.; Huang, H.; Ji, X.-J. CRISPR/Cas9-based genome editing in the filamentous fungus Fusarium fujikuroi and its application in strain engineering for gibberellic acid production. ACS Synth Biol 2019, 8, 445-454, https://doi.org/10.1021/acssynbio.8b00478. 
10. Rodrigues, C.; Vandenberghe, L.P.S.; Teodoro, J.; Oss, J.F.; Pandey, A.; Soccol, C.R. A new alternative to produce gibberellic acid by solid state fermentation. Braz Arch Biol Technol 2009, 52, 181-188, http://dx.doi.org/10.1590/S1516-89132009000700023.

11. Cen, Y.-K.; Lin, J.-G.; Wang, Y.-L.; Wang, J.-Y.; Liu, Z.-Q.; Zheng, Y.-G. The gibberellin producer Fusarium fujikuroi: Methods and technologies in the current toolkit. Front Bioeng Biotechnol 2020, 8, https://dx.doi.org/10.3389\%2Ffbioe.2020.00232.

12. Pandey, A.; Soccol, C.R.; Rodriguez-Leon, J.A.; Nigan, P.; Eds. Solid State Fermentation in Biotechnology - Fundamentals and Applications. Asiatech Publishers Inc., New Delhi; 2001.

13. Soccol, C.R.; Vandenberghe, L.P.S. Overview of applied solid-state fermentation in Brazil. Biochem Eng J 2003, 13, 205-218, https://doi.org/10.1016/S1369-703X(02)00133-X.

14. Soccol, C.R.; Vandenberghe, L.P.S.; Rodrigues, C.; Pandey, A. New perspectives for citric acid production and application. Food Technol Biotechnol 2006, 44, 141-9.

15. Ben Rhouma, M.; Kriaa, M.; Nasr, Y.B.; Mellouli, L.; Kammoun, R. A new endophytic Fusarium oxysporum gibberellic acid: Optimization of production using combined strategies of experimental designs and potency on tomato growth under stress condition. Biomed Res Int 2020, 2020, https://doi.org/10.1155/2020/4587148.

16. Kumar, P.K.R.; Lonsane, B.K. Solid state fermentation: physical and nutritional factors influencing gibberellic acid production. Appl Microbiol Biotechnol 1990, 34, 145-148, https://doi.org/10.1007/BF00166770.

17. Agosin, E.; Maureira, M.; Biffani, V.; Perez, F. Production of gibberellins by solid substrate cultivation of Gibberella fujikuroi. In: Advances in Solid State Fermentation. Roussos, S.; Lonsane, B.K.; Raimbault, M.; Viniegra-Gonzalez, G. Eds.; Springer: Dordrecht, 1997; pp. 355-366, https://doi.org/10.1007/978-94-0170661-2_29.

18. Bandelier, S.; Renaud, R.; Durand, A. Production of gibberellic acid by fed-batch solid state fermentation in an aseptic pilot-scale reactor. Process Biochem 1997, 32, 141-145, https://doi.org/10.1016/S00329592(96)00063-5.

19. Tomasini, A.; Fajardo, C. Gibberellic acid production using different solid-state fermentation systems. World J Microbiol Biotechnol 1997, 13, 203-206, https://doi.org/10.1023/A:1018545932104

20. Machado, C.M.M; Soccol, C.R.; Pandey, A. Gibberellic acid production by solid state fermentation in coffee husk. Appl Biochem Biotechnol 2002, 102, 179-192, https://doi.org/10.1385/ABAB:102-103:1-6:179.

21. Camara, M.C.; Vandenberghe, L.P.S.; Sextos, G.C.; Tanobe, V.O.A.; Magalhães Junior, A.I.; Soccol, C.R. Alternative methods for gibberellic acid production, recovery and formulation: A case study for product cost reduction. Bioresour Technol 2020,309, https://doi.org/10.1016/j.biortech.2020.123295.

22. De Oliveira, J.; Rodrigues, C.; Vandenberghe, L.P.S.; Câmara, M.C.; Libardi, N.; Soccol, C.R. Gibberellic acid production by different fermentation systems using citric pulp as substrate/support. Biomed Res Int 2017, 2017, https://doi.org/10.1155/2017/5191046.

23. Satpute, D.; Sharma, V.; Murarkar, K.; Bhotmange, M.; Tukadoji, R.; Dharmadhikari, D.; Solid-state fermentation for production of gibberellic acid using agricultural residues. Int J Environment Pollut 2010, 43, 201-213, https://doi.org/10.1504/IJEP.2010.035924.

24. Bai, J.; Liu, F.; Li, S.; Li, P.; Chang, C.; Fang, S. Solid-state fermentation process for gibberellin production using enzymatic hydrolysate corn stalks. BioRes 2020, 15, 429-443.

25. Rangaswamy, V. Improved production of gibberellic acid by Fusarium moniliforme. J Microbiol Res 2012, 2, 51-55, https://doi.org/10.5923/j.microbiology.20120203.02.

26. Werle, L.B.; Abaide, E.R.; Felin, T.H.; Kuhn, K.R.; Tres, M.V.; Zabot, G.L.; Kuhn, R.C.; Jahn, S.L.; Mazutti, M.A. Gibberellic acid production from Gibberella fujikuroi using agro-industrial residues. Biocatal Agric Biotechnol 2020, 25, https://doi.org/10.1016/j.bcab.2020.101608.

27. Dias, M.O.; Falconi D. The evolution of craft beer industry in Brazil. J Econ \& Bus 2018, 1, 618-622, https://doi.org/10.31014/aior.1992.01.04.55.

28. Brasil. Anuário da cerveja: 2019. Ministério da Agricultura, Pecuária e Abastecimento. Secretaria de Defesa Agropecuária - Brasília: MAPA/SDA 2020, pp. 16, https://www.gov.br/agricultura/ptbr/assuntos/inspecao/produtos-vegetal/publicacoes/anuario-da-cerveja-2019

29. Guimarães, B.P.; Neves, L.E.P.; Guimarães, M.G.; Ghesti, G.F. Evaluation of maturation congeners in beer aged with Brazilian woods. J Brew Distilling 2020, 9, 1-7.

30. Dias, M.O.; Teles, A. Facts and perspectives on craft brewing industry in Brazil. Int J Eng Res Manag Technol 2019, 9, 1020-1028, https://doi.org/10.13140/RG.2.2.16416.23049.

31. Godoi, C.N.; da Costa Filho, B.A.; Wander, A.E.; Lopes, P.G.; Souza, G.V. Cooperation and competitiveness in brazilian crafted beer production: The case of gypsy breweries in Goiás State. Int $J A d v$ Eng Res Sci 2019, 6, 13-30, https://dx.doi.org/10.22161/ijaers.6.6.2.

32. Cordeiro, L.G.; El-Aouar, Â.A.; Gusmão, R.P. Characterization of the bagasse coming from malt beer. Green Journal of Agroecology and Sustainable Development 2012, 7, 20-22.

33. Kavalopoulos, M.; Stoumpou, V.; Christofi, A.; Mai, S.; Barampouti, E.M.; Moustakas, K.; Malamis, D.; Loizidou, M. Sustainable valorisation pathways mitigating environmental pollution from brewers' spent grains. Environ Pollut 2021, 270, https://doi.org/10.1016/j.envpol.2020.116069. 
34. Santos, M.; Jiménez, J.J.; Bartolomé, B.; Gómez-Cordovés, C.; Del Nozal, M.J. Variability of brewer’s spent grain within a brewery. Food Chem 2003, 80, 17-21, https://doi.org/10.1016/S0308-8146(02)00229-7.

35. Karlović, A.; Jurić, A.; Ćorić, N.; Habschied, K.; Krstanović, V.; Mastanjević, K. By-products in the malting and brewing industries - Re-usage possibilities. Ferment 2020, 6, 1-17, https://doi.org/10.3390/fermentation6030082.

36. Mathias, T.R.S.; de Mello, P.P.M.; Sérvulo, E.F.C. Solid wastes in brewing process: A review. J Brew Distilling 2014, 5, 1-9, https://doi.org/10.5897/JBD2014.0043.

37. Mathias, T.R.S.; Alexandre, V.M.F.; Cammarota, M.C.; Mello, P.P.M.; Sérvulo, E.F.C. Characterization and determination of brewer's solid wastes composition. J I Brewing 2015, 121, 400-404, https://doi.org/10.1002/jib.229.

38. Jackowski, M.; Niedźwiecki, Ł.; Jagiełło, K.; Uchańska, O.; Trusek, A. Brewer’s spent grains - Valuable beer industry by-product. Biomolecules 2020, 10,. https://doi.org/10.3390/biom10121669.

39. Maqhuzu, A.B.; Yoshikawa, K.; Takahashi, F. Prospective utilization of brewers' spent grains (BSG) for energy and food in Africa and its global warming potential. Sustain Prod Consum 2021, 26, 146-159, https://doi.org/10.1016/j.spc.2020.09.022.

40. Helrich, K. Official methods of analysis of the association of official analytical chemists: Agricultural chemicals; contaminants; drugs. $15^{\text {th }}$ edition. The Association of Official Analytical Chemists - AOAC, Inc., Virginia, 1990.

41. Wongjiratthiti, A.; Yottakot, S. Utilization of local crops as alternative media for fungal growth. Pertanika J Trop Agric 2017, 40, 295-303.

42. Rodrigues, M.I.; Iemma, A.F. Experimental design and process optimization. $1^{\text {st }}$ Edition, New York, CRC Press, 2014.

43. American Society for Testing Materials - ASTM. Standard Methods G21-15, Standard Practice for Determining Resistance of Synthetic Polymeric Materials to Fungi, ASTM International, West Conshohocken, PA, 2015.

44. Berríos, J.; Illanes, A.; Aroca, G. Spectrophotometric method for determining gibberellic acid in $\begin{array}{lllll}\text { fermentation } & \text { broths. } & \text { Biotechnol } & \text { 2004, } & \text { 26, }\end{array}$ https://doi.org/10.1023/B:BILE.0000009463.98203.8b.

45. Shukla, R.; Srivastava, A.; Chand, S. Bioprocess strategies and recovery processes in gibberellic acid fermentation. Biotechnol Bioprocess Eng 2003, 8, 269-278, https://doi.org/10.1007/BF02949216.

46. Holbrook, A.; Edge, W.; Bailey, F.; Spectrophotometric method for determination of gibberellic acid. Adv Chem Ser 1961, 28, 159-167, https://doi.org/10.1021/ba-1961-0028.ch018.

47. Mussatto, S.I.; Rocha, G.J.M.; Roberto, I.C. Hydrogen peroxide bleaching of cellulose pulps obtained from brewer's spent grain. Cellullose 2008, 15, 641-649, https://doi.org/10.1007/s10570-008-9198-4.

48. Singhania, R.R.; Patel, A.K.; Soccol, C.R.; Pandey, A. Recent advances in solid-state fermentation. Biochem Eng J 2009, 44, 13-18, https://doi.org/10.1016/j.bej.2008.10.019.

49. Rios-Iribe, E.Y.; Hernández-Calderón, O.M.; Escamilla-Silva, E.M. Kinetic analysis of the uptake of glucose and corn oil used as carbon sources in batch cultures of Gibberella fujikuroi. World J Microbiol Biotechnol 2016, 32, 1-11, https://doi.org/10.1007/s11274-016-2139-8.

50. Corona, A.; Sáez, D.; Agosin, E. Effect of water activity on gibberellic acid production by Gibberella fujikuroi under solid-state fermentation conditions. Process Biochem 2005, 40, 2655-2658, https://doi.org/10.1016/j.procbio.2004.11.008.

51. Machado, C.M.M.; Oishi, B.; Pandey, A.; Soccol, C.R. Kinetics of Gibberella fujikuroi growth and gibberellic acid production by solid-state fermentation in a packed-bed column bioreactor. Biotechnol Prog 2004, 20, 1449-1453, https://doi.org/10.1021/bp049819x.

52. Cuali-Álvarez, I.; Pavón-Romero, S.H.; Colín-Cruz, A. Production of gibberellic acid by Gibberella fujikuroi using municipal residual sludge as substrate. Univ Sci 2011, 16, 51-62.

53. Díaz, L.E.; Henao, A.; Ramírez, L.A. Agricultural welsh onion waste as a source of gibberellic acid. Rev U.D.C.A Act \& Div Cient 2013, 16, 369-377.

54. Gelmi, C.; Pérez-Correa, R.; Agosin, E. Modeling Gibberella fujikuroi growth and GA 3 production in solidstate fermentation. Process Biochem 2002, 37, 1033-1040,https://doi.org/10.1016/S0032-9592(01)00314-4.

55. Holmmann, D.; Switalski, J.; Geipel, S.; Onken, U. Extractive fermentation of gibberellic acid by Giberella fujikuroi. J Biosci Bioeng 1995, 79, 594-600, https://doi.org/10.1016/0922-338X(95)94754-F.

56. Vidhya, R.; Balu, G. Process for gibberellic acid production with Fusarium moniliforme strains. Applicants: Reliance Life Science Private Limited. Int. C12P17/04. US 435/126. US n. 20080085543A1. 12 Sept. 2007. Washington, DC. 10 Apr. 2008. 